\title{
OPTIMALISASI PRODUKSI DAN PENEKANAN BIAYA PENYADAPAN DENGAN SISTEM SADAP INTENSITAS RENDAH
}

\author{
Optimization of Yield and Suppression of Tapping Cost by Low Intensity Tapping System \\ Sumarmadji, Akhmad Rouf, Yoga Bagus Setya Aji dan Titik Widyasari \\ Balai Penelitian Getas, Pusat Penelitian Karet \\ J1. Pattimura KM 6, P.O. Box 804, Salatiga, Jawa Tengah \\ Email : aronidah@yahoo.co.id atau balitgetas@yahoo.com
}

Diterima 30 Desember 2015 / Direvisi 19 April 2017 / Disetujui 28 April 2017

\begin{abstract}
Abstrak
Pengusahaan perkebunan karet saat ini masih mengalami tekanan berat yang berkepanjangan, terutama akibat harga rendah. Selain melalui aspek pasca panen, aspek prapanen juga harus memberi solusi. Diperlukan adanya suatu kajian yang komprehensif dan objektif melalui analisis teknis dan ekonomi. Pemecahan masalah melalui dua arah sekaligus (optimalisasi produksi dan penekanan biaya sadap), ternyatasulit dilakukan. Kemungkinan rasional yang dapat dilakukan adalah melalui: (1) orientasi produksi tinggi, biaya normal (penyadapan klon-klon quick starter (QS) untuk wilayah Utara katulistiwa dengan sistem sadap QS rekom, QS d4 dan Q-tap), atau (2) orientasi produksi normal, biaya rendah (penyadapan klon-klon slow starter (SS) untuk wilayah Selatan katulistiwa dengan sistem sadap SS rekom, SS d4, SS ab (ancak besar) dan SS d6). Analisis finansial menunjukkan bahwa (1) Saat harga $\mathrm{Rp}$ 13.600,- (85\% FOB) pada tingkat biaya penyadapan menghasilkan potensi keuntungan disemua sistem sadap dan biaya produksi pada tingkat kebun menghasilkan potensi keuntungan disemua sistem sadap kecuali SS d6, (2) Saat harga 100\% FOB, biaya produksi pada tingkat kebun menghasilkan potensi keuntungan tertinggi hingga terendah yaitu Q-tap, QS rekom dan QS d4 (Rp 8,9 jutaan sampai dengan Rp 400 ribuan), sedangkan klon SS mengalami kerugian. Dengan demikian, pengusahaan ini
\end{abstract}

terutama ketika harga rendahsebaiknya wilayah Utara katulistiwa menggunakan sistem sadap Q-tap dan wilayah Selatan katulistiwa menggunakan SS d4. Adapun sistem sadap SS ab meskipun memberi nilai lebih tinggi, kurang disarankan karena kurang sustainable. Pengusahaan tanaman karet akan menjadi lebih baik dansustainable, jika dikawal denganpenerapan LD secara langsung.

Kata kunci: Karet (Hevea brasiliensis), produksi optimal, penekanan biaya penyadapan, penyadapan intensitas rendah

\section{Abstract}

Business of rubber plantation now is still has high pressure and continuing, mainly due to the low price. Other than through post-harvest, preharvest aspects are also required to provide solutions. It's required a comprehensive and objective study through technical and economical analysis. Solving the problem through approach two directions at once (optimizing yield and suppression of tapping cost), it wasn't easy. Rational ways that can be applied are through: (1) Oriented of high production, normal cost (tapping on quick starter (QS) clones for northernarea of equator useQS recom, $Q S d 4$ and Q-tap tapping systems) or (2) Oriented of normal production with low cost (tapping on slow starter (SS) clones for southern use SS recom, SS d4, SS it (large task) dan SS d6 tapping systems). The financial analysis showed that (1) when the price IDR 13.600,- (85\% FOB) atlevel of direct costs of 
tapping is profitable in all tapping systems, except SS d6,(2) when the price is 100\% FOB (at the level of TSR material), the profits from the highest to the lowest respectively obtained in Q-tap, QS recom and QS $d 4$ (IDR8,9 million -400 tousand), while the SS clones having losses. Thus, this business especially in low price condition swill be better if northern area of equator appropriate to use Q-tap, and southern area of equator use SS d4. SS therefore $S S$ as giving higher value, it's less recommended due to lack sustainable. It would be much better and sustainable, if it's managed by the application of $L D$ directly.

Keywords: Rubber (Hevea brassiliensis), optimal production, suppression of cost, low tapping intensity

\section{Pendahuluan}

Pengusahaan tanaman karet saat ini kembali mengalami tekanan yang cukup berat dan berkepanjangan terutama disebabkan oleh rendahnya harga jual di tingkat nasional bahkan internasional. Situasi bisnis karet di Indonesia dan Asia Tenggara meskipun telah berlangsung sangat lama (ratusan tahun), fluktuasi pasang surut masih saja terjadi. Tanaman karet yang merupakan tanaman tahunan (perennial crop) sebenarnya tidak perlu mempertimbangkan kondisi harga sesaat namun lebih mendasarkan pada kebutuhan manusia jangka panjang akan komoditas tersebut. Kenyataannya di lapanganjika harga komoditas sedang bagus banyak pihak membuka usaha tanaman karet, sebaliknya jika harga rendah banyak pihak yang memiliki usaha tanaman karet menebang tanamannya. Padahal, investasi tanaman karet tidak dapat dilakukan secara instan namun memerlukan waktu yang panjang dengan masa tanaman belum menghasilkan juga cukup panjang (4 - 5 tahun). Oleh karena itu sebaliknya tidak serta merta jika harga bagus langsung menanam karet, karena belum tentu pada saat sudah menghasilkan akan disertai dengan harga yang bagus pula. Sejak tahun 2000-an keinginan mengusahakan tanaman karet cukup tinggi bahkan diproyeksikan akan kekurangan bahan baku pada saat konsumsi dunia sangat tinggi, dan hal ini terbukti dengan harga yang meningkat tajam hingga mencapai puncak pada tahun 2010 - 2011 . Namun setelah itu, secara cepat juga harga menurun pada tahun 2012, 2013, 2014 , 2015 hingga awal tahun 2016pada posisi harga yang rendah mendekati 1 USD/kg (TSR20).

Hampir semua pihak yang mengusahakan tanaman karet sudah tidak sanggup bertahan karena harga jual pada beberapa tahun terakhir sudah di bawah biaya pengusahaannya (harga pokok produksinya). Berbagai upaya telah dilakukan baik secara mikro (perusahaan/usahatani) maupun makro (pemerintah) bahkan situasi seperti ini juga berlangsung antar negara produsen di seluruh dunia. Maka pada kesempatan ini diperlukan pemikiran bersama khususnya ditingkat nasional baik melalui pendekatan pascapanen (industri hilir) maupun prapanen (industri hulu) untuk dapat memberikan ruang memperoleh margin keuntungan usaha yang memadai. Dalam hal pencapaian produktivitas yang tinggi juga sekaligus menurunkan biaya pokok mungkin sudah melampaui kiat-kiat yang selama ini dipahami, bahkan pemikiran untuk melakukan upaya efisiensi biaya penyadapan dengan mempertahankan produksi optimal sudah dilakukan. Hasilnya masih belum memuaskan karena banyaknya faktor yang saling berpengaruh satu sama lain. Upaya penurunan biaya penyadapan, misalnya dengan menurunkan frekuensi sadap $\mathrm{d} 3$ (menyadap 10 kali per bulan) menjadi d4 (menyadap 8 kali per bulan). Meskipun dapat mengurangi biaya produksi namun ternyata pada suatu perusahaan juga sekaligus diiringi dengan menurunnya produksi lebih signifikan lagi. Selain itu permasalahan tenaga kerja yang sudah terpasang tidak dengan mudah dapat dikurangi atau dilakukan pemutusan hubungan kerja. Oleh karena itu tulisan ini dimaksudkan untuk memberi sumbangan pemikiran terkini dan komprehensif, guna menjawab tantangan pengusahaan tanaman karet yang sedang 
tertekan. Kajian dalam tulisan ini disesuaikan dengan kondisi wilayah Utara katulistiwa (yang banyak mengadopsi klonklon QS) maupun Selatan katulistiwa (yang banyak mengadopsi klon-klon SS) di Indonesia. Masing-masing wilayah tergolong spesifik pada berbagai variabel lingkungan yang dimiliki. Kajian yang dilakukan dalam tulisan ini ditinjau dari sisi teknis agronomi dan finansial.

\section{Variasi Pendekatan Dasar dalam Penentuan Sistem Sadap}

1. Sistem Sadap Konvensional dan Tataguna Panel

Dalam sejarahnya, tataguna panel telah mengalami banyak perkembangan dan penyesuaian. Pada mulanya tataguna panel berlaku sederhana selama 25 tahun yakni 17 tahun di panel bawah, 4 tahun di panel atas, dan 4 tahun sebagai sadap bebas di panel mana saja. Panel bawah disadap 6 tahun di BO-1, 5 tahun di BO-2, 3 tahun di BI-1 dan 3 tahun di BI-2. Adapun panel atas disadap masing-masing selama 2 tahun di HO-1dan HO-2 seperti pada Gambar 1.

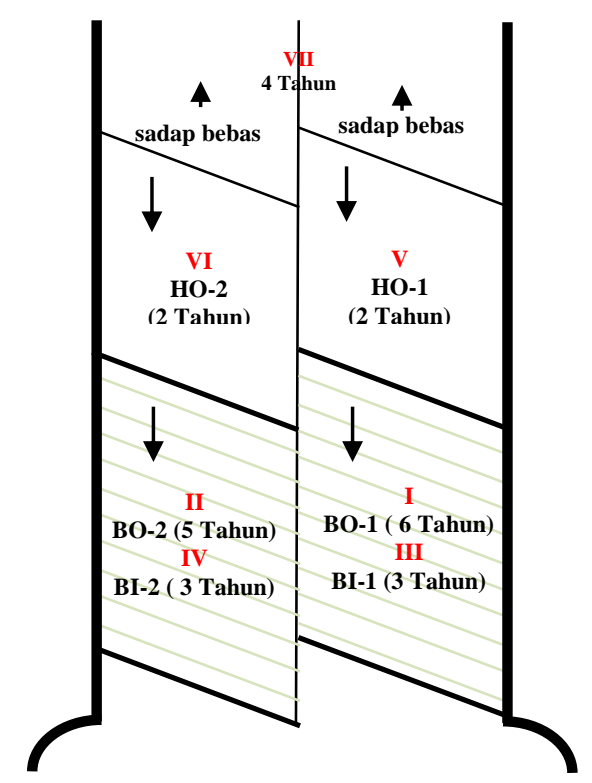

Gambar 1. Penggunaan panel pada sistem sadap konvensional

Pada sistem ini, produktivitas tanaman akan menurun saat menyadap pada kulit pulihan di panel BI-1 dan BI-2. Peningkatan produktivitas diharapkan saat penyadapan ke arah atas, namun karena telah mengalami penurunan populasi maka produksi per satuan luas tetap rendah. Meskipun memiliki siklus ekonomi yang relatif lebih panjang, produktivitas kumulatif tanaman tidak menguntungkan karena puncak produksi tidak pernah tercapai. Sementara itu disatu sisi pelaku agribisnis karet selalu dihadapkan pada satu pilihan yaitu mendapatkan produksi yang tinggi terutama berkaitan dengan harga karet. Pada saat harga karet sedang tinggi, para pelaku agribisnis dituntut untuk mendapatkan produksi yang tinggi untuk memperbesar profit margin. Begitu pula saat harga rendah, pelaku agribisnis juga harus mengambil produksi banyak untuk kompensasi biaya operasional yang cenderung meningkat.

2. Sistem Sadap Alternate Tapping System (ATS) dan Change Over Panel (COP) 
Pengusahaan tanaman karet sangat erat hubungannya dengan ketersediaan kulit sebagai bidang/panel sadapan, sehingga kulit diistilahkan sebagai modal (bast capital). Sebagaimana konsep bisnis secara umum, penggunaan modal harus dilaksanakan secara bijaksana. Tataguna panel bertujuan menggali potensi produksi di setiap bagian kulit secara optimal. Tataguna panel yang tidak tepat dapat menimbulkan dampak komplikasi.Irisan sadap di satu bagian kulit dapat menurunkan bahkan mematikan potensi produksi di bagian kulit lainnya. Dalam hal ini walaupun kulit masih tersedia, hasilnya akan nihil karena sudah terjadi efek saling memutus pada jaringan lateks. Sebaliknya, meskipun tataguna panel sudah didesain sedemikian rupa untuk menghindari efek saling memutus tersebut jika konsumsi kulit tidak terkendali maka umur ekonomis tanaman akan lebih pendek dari yang direncanakan sehingga secara kumulatif produktivitas tanaman dalam satu siklus ekonomi juga rendah. Oleh sebab itu, produktivitas tanaman karet yang tinggi dalam siklus ekonominya harus memenuhi perpaduan tataguna panel yang tepat dan konsumsi kulit yang hemat.

Dengan alasan tersebut maka dilakukan modifikasi tataguna panel menjadi COP (change over panel) dan ATS (alternate tapping system). COP yaitu perpindahan panel dari BO-1 ke BO-2 secara bergantian tiap tahun dimulai pada tahun sadap ke 4 hingga tahun sadap ke 11. Kemudian pada tahun sadap ke 12 dilanjutkan dengan ATS yang merupakan perpaduan sadap ke arah atas (SKA) dengan sadap ke arah bawah (SKB). ATS yaitu penggunaan panel atas secara bergantian tiap semester, misalnya dari HO-1 (semester 1) ke HO-2 (semester 2) dengan sistem sadap $\mathrm{S} / 2$ d4 dan dikombinasikan dengan penyadapan panel bawah secara bergantian tiap tahun dari BI-1 ke BI-2 dengan sistem sadap S/2 d3. Penyadapan COP dan ATS dapat dilakukan hingga tahun sadap ke 31 (Basuki, 1983). Secara prinsip, konsep tataguna panel ini dinilai baik karena dapat menggairahkan penyadap dengan produksi yang tinggi dan tataguna panel bersesuaian dengan musim gugur daun. Namun dalam praktiknya, penyadap cenderung hanya menggunakan panel atas saja karena dorongan produksi yang tinggi sehingga panel bawah hampir tidak pernah digunakan bahkan juga pada saat musim gugur daun. Hal ini menjadi semakin nyata jika aspek pengawasan (tap inspeksi) cenderung melemah dan tidak dilembagakan.

Situasi tersebut tentu membawa kerugian besar karena dalam waktu singkat panel atas habis akibat konsumsi kulit irisan ke atas tidak terkendali, disusul dengan kematian panel bawah (kering alur sadap/KAS) yang selalu tidak cukup terpasok asimilat akibat rusaknya panel atas (terlebih jika berlaku COP). Pada gilirannya produktivitas tanaman akan menurun tajam, sementara ketersediaan kulit (bast capital) sudah kritis. Itulah sebabnya banyak kebun karet di berbagai wilayah mengalami percepatan siklus sadap, hanya berkisar $10-12$ tahun saja karena tidak ada lagi panel sadap yang tersedia. Standar 25 tahun sadap (30 tahun siklus ekonomi) yang dicanangkan ternyata jarang dapat dipenuhi. Banyak perusahaan bertahan untuk tidak melakukan peremajaan hingga mencapai umur ekonomis yang ditentukan (karena memerlukan biaya investasi besar), padahal produksi tanaman sudah tidak ekonomis lagi. Dalam hal tersebut, pengusahaan tanaman karet hanya memperpanjang kerugian dari waktu ke waktu. Hasil pengamatan di berbagai lokasi menunjukkan bahwa produksi kumulatif hanya berkisar 20 ton/ha/siklus (maksimal tercatat hanya 26 ton/ha/siklus), sementara potensi normalnya adalah $35-40$ ton/ha/siklus. Situasi kronologis ini perlu dipahami bersama agar dapat diambil pelajaran dan diantisipasi lebih lanjut oleh para pelaku agribisnis tanaman karet.

\section{Sistem Sadap Berdasar Tipologi Klon}

Sejalan dengan Perkembangan Pemuliaan tanaman karet telah dihasilkan beragam klon unggul baru. Walaupun demikian ternyata tidak semuanya dapat diperlakukan sesuai 
dengan sistem eksploitasi yang ada (Junaidi et al., 1995; Jacob et al., 1995). Setiap klon memiliki sifat yang spesifik termasuk klonklon baru yang memiliki produktivitas tinggi, namun sebagian sangat peka terhadap serangan KAS, kulit pulihan yang cenderung benjol-benjol, serta kurang responsif terhadap pemberian stimulan. Sedangkan sebagian klon yang lain masih dianggap sesuai jika diberi perlakuan sistem sadap konvensional.

Aplikasi stimulan pada awalnya ditujukan untuk meningkatkan efisiensi penggunaan tenaga penyadap, dalam hal tersebut hampir di semua perusahaan perkebunan karet saat ini berlaku baku teknis pemberian stimulan. Bahkan dengan banyaknya produk yang ditawarkan di pasaran, maka timbul anggapan bahwa pemberian stimulan adalah keputusan untuk meningkatkan produksi. Hal tersebut tidak sepenuhnya benar karena pemberian stimulan yang tidak sesuai dengan karakter fisiologis tanaman seringkali menurunkan kesehatan tanaman (Gohet et al., 1996) dan selanjutnya secara keseluruhan menurunkan produksi. Sumarmadji (2000) menyatakan bahwa penyadapan yang berlebihan menyebabkan produksi yang berlebihan pada periode awal dan diikuti oleh keletihan fisiologis (secara mudah terlihat dari angka DRC yang rendah) sehingga dalam jangka panjang justru menurunkan produksi dan sulit untuk diperbaiki. Sebaliknya kekurangan intensitas sadap menyebabkan kapasitas produksi tanaman tidak dapat dikeluarkan secara optimal. Kedua kondisi tersebut akhirnya menimbulkan akibat yang sama yakni produktivitas tanaman karet dalam satu siklus ekonomi tidak tercapai.

\section{Sistem Sadap dengan Pendekatan Latex Diagnosis (LD)}

Untuk mengetahui secara pasti stamina tanaman, idealnya perlu diketahui indikator fisiologis yang berhubungan dengan proses sintesis (metabolisme pembentukan) lateks atau partikel karet (poli-isoprena). Diagnosis lateks (LD) adalah suatu konsep yang dikembangkan untuk mengidentifikasi peubah-peubah dalam lateks yang berhubungan erat dengan proses sintesis lateks dalam jaringan pembuluh lateks (Jacob et al., 1989; Tistama dan Siregar, 2005; Rachmawan et al., 2006). Sampel lateks diambil pada periode tajuk daun sedang penuh (window period) kemudian dianalisis kadar sukrosa, fosfat anorganik (Pi), tiols (R$\mathrm{SH}$ ), dan padatan kering (TSC) dalam lateks. Dari hasil analisis ini kemudian didiagnosis secara tepat dan spesifik perlakuan sistem sadap yang sesuai pada masing-masing field/blok atau hamparan tanaman tertentu.

Penerapan LD di tingkat kebun atau perusahaan karet adalah menentukan status fisiologis terkait dengan proses pembentukan lateks sehingga dapat diarahkan untuk memperoleh produksi optimal. Caranya adalah dengan menetapkan faktor intensitas sadap yakni panjang irisan (S) yang tetap (misalnya S/2 pada panel bawah dan S/4U pada panel atas), dan frekuensi sadap (d) juga tetap (misalnya d4), kemudian aplikasi stimulan (ET) sebagai variabel yang ditentukan oleh hasil LD (misalnya stop, 4/y, 6/y, 12/y dst hingga 18/y, 22/y atau lebih, atau dari $2,5 \%$ menjadi $3,5 \%$ hingga $5,0 \%)$.

Identifikasi karakter fisiologis masingmasing hamparan tanaman ini (tahun tanam, klon, kondisi tanaman, sadapan dan lingkungan) menunjukkan apakah sukrosa sebagai bahan baku isoprenanya cukup, aktivitas metaboliknya (Pi) memadai, daya tahan antioksidannya (tiols) memadai dan apakah total padatan keringnya (TSC) menunjukkan proses regenerasi lateks in situ nya berjalan normal. Secara khusus identifikasi variabel LD dapat untuk mengetahui sifat-sifat fisiologis masingmasing klon dan selanjutnya dapat memperkirakan sistem sadap yang sesuai dengan karakter fisiologis klon tersebut.

\section{Sistem Sadap dengan Pendekatan \\ Rekomendasi Sistem Sadap \\ Pengenalan karakter fisiologis dengan variabel-variabel LD pada masing-masing tipologi klon tersebut bermanfaat untuk}


mengarahkan sistem sadap yang sesuai. Dalam hal ini, untuk kepentingan yang lebih luas dan tidak mengharuskan tersedianya fasilitas laboratorium dan petugas khusus di setiap wilayah, maka telah dikembangkan pula pendekatan lain melalui klasifikasi klon berdasarkan ciri metabolisme pembentukan lateks (Sumarmadji dan Tistama, 2004). Kajian tipologi klonal (Jacob et al., 1995; Sumarmadji, 1999) ini dilakukan untuk mengiventarisasi klon-klon anjuran yang sudah tersebar luas dalam suatu kelompokkelompok yang memiliki kemiripan dalam metabolisme pembentukan lateksnya. Hasil inventarisasi tersebut diperoleh dua kelompok besar klon yaitu klon-klon quick starter dan klon-klon slow starter.

Klon-klon quick starter (QS) adalah klon dengan metabolisme tinggi yang memiliki sifat antara lain kurang responsif terhadap pemberian stimulan, rentan terhadap KAS, dan kulit pulihan yang kurang potensial. Sedangkan klon slow starter (SS)adalah klon dengan metabolisme rendah sampai sedang yang memiliki ciri spesifik diantaranya responsif terhadap pemberian stimulan relatif lebih tahan terhadap tekanan eksploitasi dan kulit pulihan umumnya tebal sehingga potensial untuk dimanfaatkan (Siregar et al., 2008). Beberapa jenis klon yang banyak digunakan di Indonesia telah dibedakan berdasarkan pengelompokan seperti yang disajikan pada Tabel 1.

Bukit et al. (2006) melakukan penelitian terhadap potensi produksi per hektar dari kedua jenis klon tersebut yang hasilnya sejalan dengan hasil pengamatan Azwar dan Suhendry (1998) bahwa keduanya memiliki pola produksi yang berbeda. Klon QS memiliki puncak produksi yang diperoleh pada periode awal penyadapan, sedangkanklon SS memiliki puncak produksi pada pertengahan siklus ekonominya. Klasifikasi klon yang sudah tersusun tersebut dapat dijadikan dasar dalam penetapan sistem sadap yang sesuai, sehingga dapat mendukung produktivitas tanaman yang optimal, tidak akan terjadi over dan under eksploitasi. Pendekatan ini dianggap praktis karena dapat digunakan oleh semua pelaku agribisnis perkebunan karet, meskipun tidak secermat dan seteliti penggunaan konsep Diagnosis Lateks.

Klasifikasi klon berdasarkan metabolisme pembentukan lateks ini selanjutnya akan terus dikembangkan dan disempurnakan, terutama untuk mendukung penyusunan rekomendasi sistem eksploitasi tanaman karet (Sumarmadji et al., 2006; Siregar et al., 2008). Perakitan klon-klon baru dalam program pemuliaan tanaman karet saat ini juga didukung oleh data tipologi klonal, sehingga setiap pelepasan klon baru sudah dapat disertai dengan rekomendasi sistem eksploitasi yang sesuai (Sumarmadji, 2004).

Tabel 1. Contoh jenis-jenis klon berdasarkan metabolisme lateks

\begin{tabular}{cl}
\hline Jenis klon & \multicolumn{1}{c}{ Contoh klon } \\
\hline Quick & PB 235, PB 260, PB 280, PB 340, RRIM 712, IRR 1, IRR 2, IRR 3, \\
starter & IRR 4, IRR 5, IRR 6, IRR 7, IRR 8, IRR 10, IRR 103, IRR 104, IRR \\
(QS) & 105, IRR 106, IRR 230, IRR 109, IRR 110, IRR 111, IRR 112, IRR \\
& 117, IRR 118, IRR 119, IRR 120 \\
\hline Slow & GT 1, BPM 1, BPM 24, BPM 107, BPM 109, PR 255, PR 261, PR \\
starter & 300, PR 303, PB 217, PB 330, RRIC 100, RRIC 102, RRIC 110, \\
(SS) & RRIM 717, IRR 9, AVROS 2037, TM 2, TM 6, TM 8, TM 9. \\
\hline
\end{tabular}




\section{Kajian Teknis Sistem Sadap}

Kajian teknis yang dikaji dalam tulisan ini meliputi sistem sadap berorientasi produksi tinggi dan sistem sadap intensitas rendah berorientasi menekan biaya penyadapan.

\section{A. Sistem Sadap Berorientasi Produksi Tinggi}

1. Rekomendasi Klon Quick Starter (QS rekom)

Klon-klon quick starter memiliki beberapa sifat spesifik diantaranya produksi awal tinggi, kurang responsif terhadap pemberian stimulan, rentan terkena KAS, dan kulit pulihan kurang potensial sehingga sistem sadap untuk klon ini tidak menggunakan kulit pulihan dan cocok menggunakan irisan pendek ke arah atas (S/4U d3). Penggunaan stimulan untuk klon ini juga dibatasi maksimal 12 kali per tahun untuk menghindari kelelahan tanaman secara fisiologis.

Tataguna panel dimulai pada kulit BO-1 dari ketinggian $130 \mathrm{~cm}$ dengan sistem sadap $\mathrm{S} / 2$ d3ET2,5\% selama 5 tahun. Setelah itu penyadapan dilanjutkan ke BO-2 namun diturunkan pada ketinggian $80 \mathrm{~cm}$ dengan sistem sadap yang sama selama 2 tahun. Sisa kulit di BO-2 sekitar $30 \mathrm{~cm}$ hanya disadap pada saat gugur daun. Penyadapan selanjutnya adalah pada panel HO-1 selama empat tahun hingga ketinggian $220 \mathrm{~cm}$ dengan sistem sadap S/4U d3ET2,5\%, dilanjutkan pada $\mathrm{HO}-2$ di atas $80 \mathrm{~cm}$ dengan sistem sadap yang sama selama 6 tahun hingga ketinggian yang sama yakni $220 \mathrm{~cm}$. Setelah itu berlaku sadap bebas selama 3 tahun, maka diharapkan siklus penyadapan dapat dilakukan selama 20 tahun dengan perkiraan produktivitas total 40 ton/ha/siklus tanaman (Tabel lampiran 1).

Umumnya akselerasi penggunaan kulit terjadi ketika penyadapan dilakukan ke arah atas. Perpindahan panel atas dapat dilakukan setiap satu tahun, dengan asumsi penggunaan kulit maksimal $2,5 \mathrm{~mm} / \mathrm{sadap}$ dan hari sadap efektif mencapai 115 hari/tahun, maka konsumsi kulit selama satu tahun seharusnya tidak akan melebihi $30 \mathrm{~cm}$ sehingga tidak akan menyebabkan penurunan potensi produksi panel berikutnya. Namun asumsi tersebut juga sulit diterapkan di lapangan karena keborosan pemakaian kulit, konsumsi per tahun dapat mencapai 60$70 \mathrm{~cm}$. Oleh sebab itu, pengawasan di lapangan mutlak diperlukan. Untuk mencegah jarak antar panel yang terlalu jauh perpindahan dapat disesuaikan dalam rentang 15-20 cm per satu semester.

2. Modifikasi QS (QS d4)

Sementara sedang berlangsung penyadapan tanaman karet dengan pola rekomendasi QS, ternyata terjadi situasi harga karet yang tetap rendah dalam waktu yang agak lama (periode 2012 - 2015). Oleh karena itu upaya efisiensi dilakukan dengan penggunaan frekuensi sadap d4 (yang sebelumnya d3) terutama pada panel basal hingga TM 4. Praktik penggunaan frekuensi sadap d4 pada pola rekomendasi QS ini terbukti memberikan dampak terhadap penurunan produksi yang cukup signifikan yakni sekitar 20\% dari biasanya (setara dengan penurunan hari sadap yang biasanya 10 kali menjadi 8 kali sebulan). Nang et al. (2015) melaporkan bahwa penurunan frekuensi sadap dari d3 menjadi d4 dapat meningkatkan hasil gram per pohon per sadap $(\mathrm{g} / \mathrm{p} / \mathrm{s})$ pada klon PB 260 dengan ratarata 52,0 gram dibandingkan dengan frekuensi sadap $\mathrm{d} 3$ yang hanya menghasilkan rata-rata 43,2 gram pada berbagai frekuensi stimulan. Namun selama 4 tahun penyadapan, perlakuan frekuensi sadap d4 menghasilkan rata-rata produksi kumulatif per tahun lebih rendah yaitu $1.763 \mathrm{~kg} / \mathrm{ha} / \mathrm{th}$ dibandingkan dengan perlakuan frekuensi sadap d3 yang menghasilkan produksi kumulatif $1.941 \mathrm{~kg} / \mathrm{ha} / \mathrm{th}$. Penurunan jumlah hari sadap per tahun sangat mempengaruhi kumulatif hasil pada frekuensi sadap d4.

Upaya penurunan frekuensi sadap dilakukan sebenarnya juga untuk menertibkan sistem sadap yang sudah semakin boros dalam penggunaan kulit, dan sebagai pembandingan terhadap praktik penyadapan pada perusahaan lain dengan $\mathrm{d} 4$ 
yang terbukti dapat berjalan baik dengan produktivitas cukup tinggi $(1.800-2.000$ $\mathrm{kg} / \mathrm{ha}$ ). Dalam hal ini yang khusus membedakan adalah komposisi klon dan penerapan analisis lateks (Latex Diagnosis).Fenomena yang sedang berlangsung ini secara teknis akan dibahas apakah kelebihan dan kekurangannya, sekaligus akan diperhitungkan dampak secara ekonomis sehingga dapat memberi gambaran yang realistis, kemudian menjadi panduan bagi para pekebun/usahatani karet dalam situasi seperti saat ini.

3. Sistem Sadap Q-tap (konsep baru)

Klon Quick Starter adalah klon dengan produktivitas tinggi diawal namun dikenal rawan terhadap gangguan angin, kering alur sadap, dan tidak responsif terhadap stimulan. Secara umum di wilayah Utara Sumatera penurunan produksi disebabkan oleh angin dan jamur akar putih (JAP) karena dapat menurunkan populasi tanaman sehingga menyebabkan rendahnya produksi. Kendala lain yang dijumpai pada penyadapan klon QS adalah KAS pada panel bawah (BO1/BO-2).

Obsesi untuk memperoleh produksi kumulatif maksimal di wilayah ini adalah produksi mencapai minimal 35 ton/ha/siklus dalam periode singkat penyadapan misalnya 15 tahun saja. Penyadapan dengan periode panjang dan mengharapkan produksi dari kulit pulihan nampaknya sudah tidak relevan untuk dikembangkan dengan populasi yang akan cepat menurun. Penerapan sistem sadap irisan pendek ke arah atas (SKA) dan aplikasi stimulan sejak buka sadap diharapkan dapat menjadi peluang untuk meningkatkan produksi. Lukman (1995) menyatakan bahwa produktivitas tanaman dengan penerapan SKA lebih tinggi dibandingkan dengan sistem sadap ke arah bawah (SKB). Keuntungan lain sistem sadap ini adalah tidak menyebabkan meningkatnya KAS dan tidak menghambat pertumbuhan lilit batang (Junaidi dan Kuswanhadi, 1997).

Hasil penelitian sebelumnya telah didapatkan sistem SKA yang diberi nama EXPEX-315 (Sumarmadji dan Junaidi,
2008). Sistem exploitasi EXPEX-315 menggunakan irisan pendek $20 \mathrm{~cm}$ ke arah atas (Sc20U) dengan aplikasi stimulan sejak awal buka sadap dimulai dari $30 \mathrm{~cm}$ diatas pertautan okulasi. Data produksi selama 4 tahun pertama penyadapan dapat mencapai $10.322 \mathrm{~kg} / \mathrm{ha}$, namun masih memiliki kendala teknis. Beberapa kendala teknis yang dihadapi pada aplikasi EXPEX-315 di antaranya adalah sulitnya penyadapan pada tahun ke-1 dan ke-2, konsumsi kulit yang boros, dan membutuhkan pisau khusus.

Berdasarkan hasil penelitian tersebut, maka perlu dirakit sebuah sistem sadap baru yang dapat menutupi kendala-kendala yang dihadapi. Modifikasi sistem sadap yang akan diterapkan ini dinamakan Q-tap. Sistem sadap ini memiliki obsesi yang sama dengan EXPEX-315 namun dengan modifikasi buka sadap pada ketinggian $80 \mathrm{~cm}$. Desain sistem sadap Q-tap disajikan pada Gambar 3. Q-tap diharapkan mampu mendukung produksi total mencapai minimal 35 ton/ha/siklus dalam periode waktu yang lebih singkat. Selain itu sistem sadap ini diduga memiliki keuntungan lain yaitu dapat mengurangi KAS, dapat dimulai lebih cepat (TBM 3 atau TBM 4), dan tidak membutuhkan pisau khusus.

Hasil evaluasi terakhir di beberapa perusahaan didapati fakta bahwa meskipun produktivitas tahunan secara rata-rata tinggi (1700 kg/ha) namun kumulatif yieldnya masih sangat rendah (19-30 ton/ha/siklus) dengan waktu sadap hanya 15 tahun. Masalah-masalah tersebut yang masih terjadi perlu segera diberikan solusi dengan alternatif paling realistis, mudah, dan dapat diterapkan dengan cepat untuk menjawab kebutuhan tersebut. Oleh karena itu sistem sadap Q-tap ini diperlukan agar penyadapan tanaman QS di wilayah Utara dapat dilakukan dengan efisien, mudah dan tepat.Kurva produksi dari pola sadap Q-tap ini sepertinya realistis yakni meningkat mencapai maksimal - kemudian menurun secara bertahap - sehingga lebih alamiah mengikuti pola psikologi masa para pelaksana di lapangan (Gambar 2). 


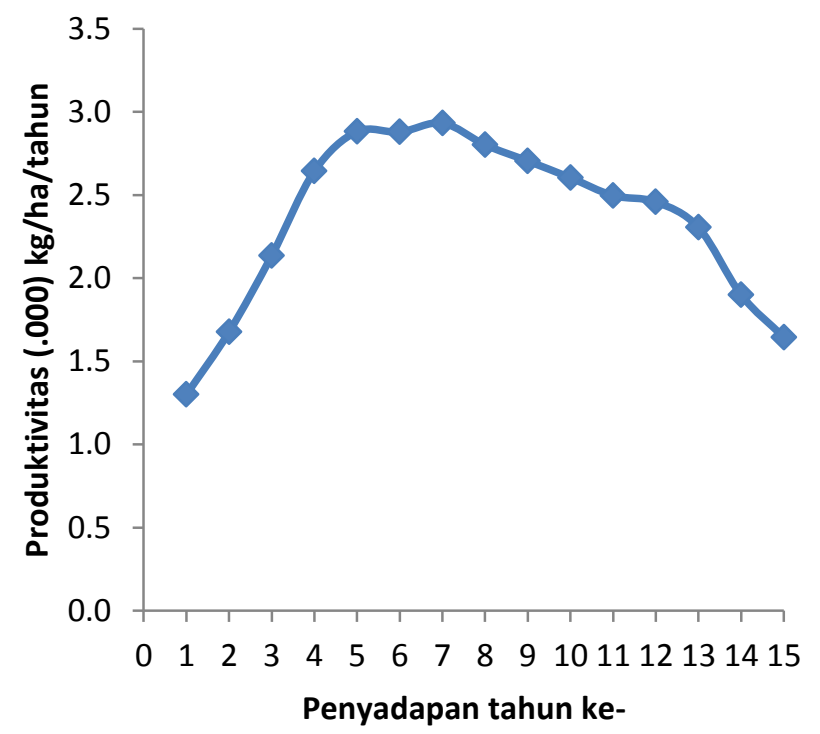

Gambar 2. Hipotesis pola produktivitas sistem sadap Q-tap yang sigmoid

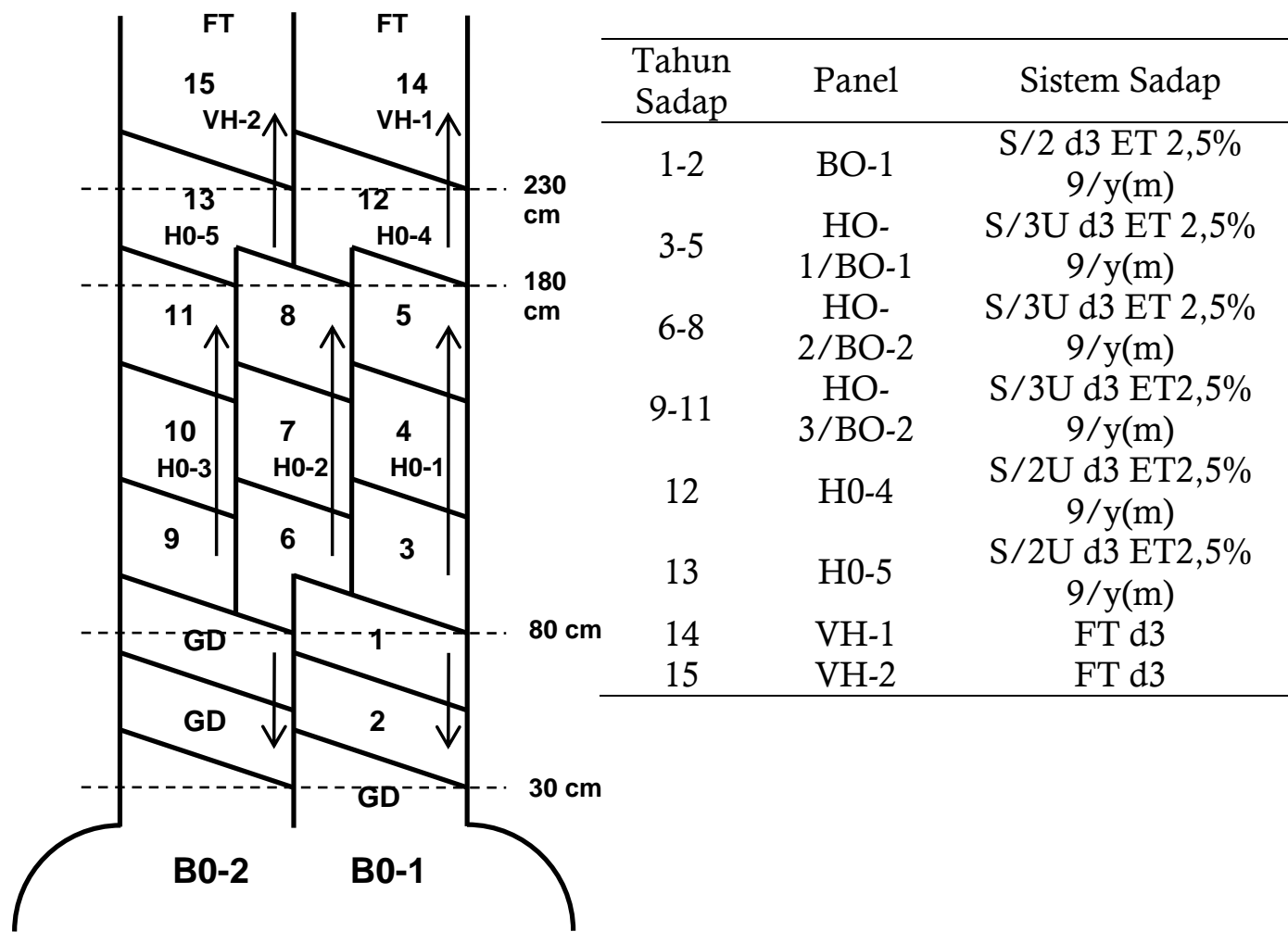

Gambar 3. Tataguna paneldan sistem eksploitasi Q-tap 
Tabel 2. Hipotesis produktivitas ( $\mathrm{kg} / \mathrm{ha} / \mathrm{tahun})$ dengan penggunaan sistem sadap Q-tap

\begin{tabular}{|c|c|c|c|c|c|}
\hline $\begin{array}{l}\text { Tahun } \\
\text { Sadap }\end{array}$ & $\mathrm{g} / \mathrm{p} / \mathrm{s}$ & $\mathrm{ph} / \mathrm{ha}$ & hari/th & $\begin{array}{c}\mathrm{kg} / \mathrm{ha} / \mathrm{t} \\
\mathrm{h}\end{array}$ & Posisi Panel \\
\hline 1 & 23 & 500 & 113 & 1.300 & BO-1 \\
\hline 2 & 28 & 530 & 113 & 1.677 & BO-1 \\
\hline 3 & 35 & 540 & 113 & 2.136 & $\begin{array}{c}\mathrm{HO}-1 / \mathrm{BO}-1 \\
\text { (MGD) }\end{array}$ \\
\hline 4 & 45 & 520 & 113 & 2.644 & $\begin{array}{c}\mathrm{HO}-1 / \mathrm{BO}-1 \\
\text { (MGD) }\end{array}$ \\
\hline 5 & 50 & 510 & 113 & 2.882 & $\begin{array}{c}\mathrm{HO}-1 / \mathrm{BO}-1 \\
\text { (MGD) }\end{array}$ \\
\hline 6 & 52 & 490 & 113 & 2.879 & $\begin{array}{c}\mathrm{HO}-2 / \mathrm{BO}-2 \\
(\mathrm{MGD})\end{array}$ \\
\hline 7 & 59 & 440 & 113 & 2.933 & $\begin{array}{c}\mathrm{HO}-2 / \mathrm{BO}-2 \\
(\mathrm{MGD})\end{array}$ \\
\hline 8 & 62 & 400 & 113 & 2.802 & $\begin{array}{c}\mathrm{HO}-2 / \mathrm{BO}-2 \\
(\mathrm{MGD})\end{array}$ \\
\hline 9 & 63 & 380 & 113 & 2.705 & $\begin{array}{c}\mathrm{HO}-3 / \mathrm{BO}-2 \\
\text { (MGD) }\end{array}$ \\
\hline 10 & 64 & 360 & 113 & 2.604 & $\begin{array}{c}\mathrm{HO}-3 / \mathrm{BO}-2 \\
(\mathrm{MGD})\end{array}$ \\
\hline 11 & 65 & 340 & 113 & 2.497 & $\begin{array}{c}\mathrm{HO}-3 / \mathrm{BO}-2 \\
\text { (MGD) }\end{array}$ \\
\hline 12 & 68 & 320 & 113 & 2.459 & $\mathrm{HO}-4$ \\
\hline 13 & 68 & 300 & 113 & 2.305 & $\mathrm{HO}-4$ \\
\hline 14 & 58 & 290 & 113 & 1.900 & VH-1 \\
\hline 15 & 52 & 280 & 113 & 1.645 & VH-2 \\
\hline \multicolumn{4}{|c|}{ Total Produksi Kumulatif } & 35.368 & \\
\hline
\end{tabular}

\section{B. Sistem Sadap Intensitas Rendah Berorientasi Menekan Biaya Penyadapan}

1. Rekomendasi Klon Slow Starter (SS rekom)

Klon-klon slow starter (SS) umumnya memiliki produksi awal rendah sampai sedang, responsif hingga sangat responsif terhadap pemberian stimulan dan kulit pulihan umumnya tebal dan sangat potensial untuk dieksploitasi. Aplikasi stimulansia dapat dilakukan dengan lebih leluasa sampai dengan 18 kali per tahun dengan interval 2 kali per bulan karena klon ini relatif lebih tahan terhadap tekanan eksploitasi. Sistem sadap untuk klon SS ditujukan untuk mengoptimalkan potensi kulit pulihan dengan kombinasi penggunaan irisan ke arah atas yang efisien. Pada tahun pertama sampai tahun ke lima penyadapan dilakukan pada panel BO-1 dengan sistem sadap $\mathrm{S} / 2$ d3ET2,5\%. Tahun keenam sampai kesepuluh masih menggunakan sistem sadap $\mathrm{S} / 2$ d3ET2,5\% pada panel BO-2. Kemudian selama empat tahun digunakan sistem sadap ganda (double cut) S/2 d3 + S/4U d3 ET2,5\% pada panel BI-1dan HO-1. Selanjutnya, selama empat tahun penyadapan dilakukan pada panel BI-2 dan HO-2 dengan sistem sadap S/2 d3 + S/4U d3ET2,5\%. Ditambah 2 tahun sadap bebas, maka diharapkan siklus ekonomi dapat mencapai 20 tahun dengan total produktivitas tanaman 35 ton/ha/siklus tanaman (Lampiran 2). Tata guna panel dapat dilihat pada Gambar 4. 
Seperti halnya pada tataguna panel klon QS, dalam sistem sadap klon SS juga terdapat kendala yang sering dijumpai yaitu saat perpindahan dari panel BO-2 ke sistem sadap ganda/double cut (DC). Sistem sadap ganda dapat meningkatkan produktivitas tanaman karena didukung produksi dari panel atas $(\mathrm{S} / 4 \mathrm{U})$ dan panel pulihan $(\mathrm{S} / 2)$, namun jika diterapkan tidak serempak pada satu hamparan peningkatan produksi juga tidak signifikan. Kecenderungan pekebun untuk segera menerapkan sistem sadap DC menyebabkan banyak kasus panel BO-2 ditinggalkan dalam keadaan belum tuntas. Panel BO-2 yang ditinggalkan merupakan kerugian tersendiri karena setelah tidak disadap beberapa tahun BO-2 tersebut kebanyakan mengalami KAS.

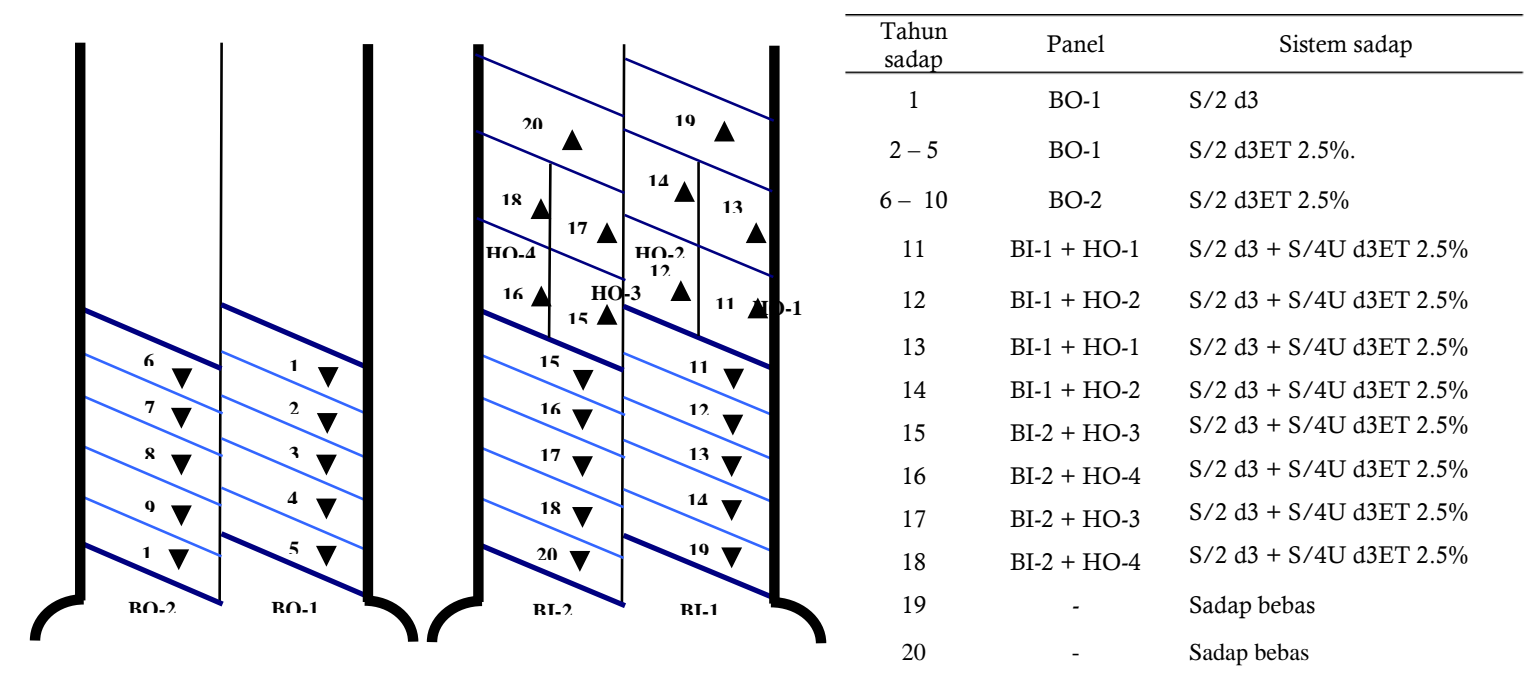

Gambar 4. Tataguna panel untuk klon-klon slow starter

2. Sistem Sadap SS Alternatif (d4, d6 dan ancak besar)

Sistem sadap intensitas rendah (lowintensitytappingsystem, LITS) dalam pengertian umum semestinya mencakup keseluruhan faktor intensitas sadapnya yang rendah, misalnya faktor panjang irisan (S), frekuensi sadap (d) dan aplikasi stimulan (ET) (Sumarmadji, 2005). Hal yang perlu dipertimbangkan dalam penerapan penyadapan dengan intensitas rendah adalah penurunan produksi per hektar dibandingkan dengan sistem penyadapan konvensional yang selama ini dilaksanakan. Penyadapan intensitas rendah menghasilkan produksi per pohon per sadap yang lebih tinggi, namun menghasilkan produksi per ha yang lebih rendah jika dibandingkan dengan penyadapan intensitas tinggi (Ting et al., 1985; Obouayeba et al., 2015). Penurunan produksi, terutama disebabkan berkurangnya jumlah hari penyadapan per tahun. Oleh karena itu diperlukan teknologi yang tepat, agar penurunan produksi dapat diminimalkan. Teknologi yang dapat diterapkan diantaranya adalah pemilihan klon yang cocok dengan intensitas penyadapan rendah dikombinasikan dengan perlakuan stimulan (Kurnia, 2006).

Pengenalan LITS seringkali bermakna ambivalen karena suatu sistem sadap intensitas rendah misalnya frekuensi sadap d3 menjadi d4 hingga d6, selalu disertai dengan penambahan intensitas stimulan. Demikian pulapenggunaan irisan pendek (S/8U atau $\mathrm{S} / 4 \mathrm{U}$ ) disertai dengan stimulan gas etilen (ETG). Oleh karena itu pengertian praktis LITS lebih bermakna untuk mengefisienkan baik secara teknis maupun ekonomis.

Beberapa alternatif yang saat ini cocok untuk diperbandingkan sebagai sistem sadap intensitas rendah guna penekanan biaya produksi antara lain adalah 1) sistem sadap 
QS d4, 2) sistem sadap SS d4, dan 3) sistem sadap ancak besar (>700 pohon) dengan periode sadap panjang. Rekomendasi sistem sadap QS sebenarnya sudah sejalan dengan karakter klon yang high metabolism yang berarti proses pengisian (regenerasi) lateks memang cepat sehingga dianggap sudah sesuai dengan frekuensi sadap $\mathrm{d} 3$, bahkan jika dilakukan tanpa stimulan pada penyadapan $\mathrm{d} 2$ akan memberikan produksi kumulatif yang lebih tinggi (Syarifa et al., 2007). Namun karena harga pokok yang semakin tinggi maka pada suatu perusahaan tetap mengupayakan penggunaan frekuensi sadap rendah d4. Biaya menurun akibat berkurangnya penggunaan tenaga penyadap, namun ternyata juga disertai dengan penurunan produksi yang nyata sehingga tidak dapat meningkatkan margin keuntungan. Efisiensi biaya tidak mampu menahan penurunan pendapatan akibat produksi yang menurun nyata. Pada kasus perusahaan tertentu dengan komposisi klon campuran QS dan SS, dan penggunaan frekuensi sadap d4 secara konsisten sejak 1985 ternyata dapat memberikan hasil yang cukup memuaskan (produksi tinggi dan biaya rendah) karena terkawal langsung dengan aplikasi Latex Diagnosis (LD). Selain penggunaan frekuensi sadap rendah, peningkatan produksi dapat dicapai dengan penggunaan sistem sadap ancak besar. Namun demikian, tingginya target produksi yang dibebankan kepada penyadap, dalam hal ini menambah jumlah pohon per ancak, justru pada akhirnya membawa efek psikologis yang mendorong penyadap tidak lagi mengindahkan fungsi TAP kontrol yang berdampak pada umur ekonomis tanaman rendah (Siregar et al., 2013).

\section{Pembahasan}

\section{Analisis Teknis}

Dalam teknologi pemanenan lateks (latex harvesting technology), telah diketahui bahwa produksi optimal dapat dicapai dengan landasan karakter fisiologi (tipologi klonal) yang dapat diidentifikasi melalui LD (diagnosis lateks) atau sistem penyadapan menggunakan rekomendasi pada klon QS atau klon SS. Penerapan sistem sadap tersebut dapat dikelompokkan menjadi dua pilar yakni QS menuju produksi tinggi dengan biaya normal, dan SS menuju produksi normal dengan biaya rendah. Nampaknya alternatif ideal mencapai produksi tinggi sekaligus biaya rendah masih sulit diperoleh. Mungkin penerapan LD (diagnosis lateks) secara konsisten dapat membuka peluang yang ideal ini, namun selama ini penerapannya masih terbatas karena membutuhkan fasilitas laboratorium sekitar kebun dan mekanisme analisis rutin tahunan pada saat kondisi tajuk terbaik (window period).

Secara teknis, mendesain sistem sadap yang tepat untuk memperoleh produksi optimal adalah menyesuaikan respon tanaman terhadap ketiga faktor intensitas sadap yakni panjang irisan, frekuensi sadapdanstimulan menjadi paket sistem sadap sebagai aksi yang merupakan komponen biaya panen. Jika aksi ini dilaksanakan maka akan menimbulkan reaksi (out put) yang dalam hal ini adalah produksi sebagai pendapatan. Produksi yang tinggi cenderung menggunakan klon QS dan tenaga kerja (jumlah HK) yang memadai, sebaliknya untuk efisiensi biaya penyadapan cenderung diterapkan pada klon SS dengan tenaga kerja yang rendah, disubstitusi dengan bahan stimulan. Untuk lebih jelasnya dapat dilihat perbandingan perhitungan teknis dan finansial pada model penyadapan QS dan turunannya (QS rekom, QS d4 dan Q-tap) dan model penyadapan SS dan turunannya (SS rekom, SS d4, SS ancak besar dan SS d6).

Ada 7 macam kombinasi sistem sadap yang dikaji dalam makalah ini, yaitu :

a. QS rekom : merepresentasikan sistem sadap yang berorientasi produksi tinggi sesuai potensi klon QS dengan biaya normal.

b. QS d4 : merepresentasikan sistem sadap yang berorientasi produksi tinggi dengan 

biaya rendah melalui
f. SS d6
penurunan frekuensi sadap dari $\mathrm{d} 3 \mathrm{ke} \mathrm{d} 4$
c. Q-tap : merupakan konsep baru sistem sadap QS sesuai ekologi, produksi tinggi dalam periode singkat
d. SS rekom : merepresentasikan sistem sadap yang berorientasi produksi optimal sesuai potensi klon SS dengan biaya normal.
e. SS d4 : merepresentasikan sistem sadap pada klon SS dengan biaya rendah melalui penurunan frekuensi sadap dari $\mathrm{d} 3$ ke $\mathrm{d} 4$
merepresentasikan sistem sadap pada klon SS dengan biaya lebih rendah melalui penurunan frekuensi sadap dari $\mathrm{d} 3 \mathrm{ke} \mathrm{d} 6$
g. SS ab : merepresentasikan sistem sadap SS rekom dengan memodifikasi ukuran ancak menjadi lebih besar (700 pohon/ancak)
Hasil pembandingan (umur TM VII) dapat dilihat pada Tabel 3, masing-masing sistem sadap menunjukkan dua kelompok hasil produksi, yaitu produksi tinggi dicapai pada klon QS (1.721-2.565 kg/ha) dan produksi normal dicapai pada klon SS (1.170- $1620 \mathrm{~kg} / \mathrm{ha}$ ).

Tabel 3. Masing-masing sistem sadap dengan deskripsi yang membedakan dan produktivitas yang dihasilkan

\begin{tabular}{|c|c|c|c|c|c|c|c|}
\hline $\begin{array}{l}\text { Sistem } \\
\text { Sadap }\end{array}$ & Notasi Sadap & Panel & $\begin{array}{c}\text { Protas } \\
\text { (gps) }\end{array}$ & $\begin{array}{c}\text { Intensitas } \\
\text { Relatif } \\
\end{array}$ & $\begin{array}{l}\text { Pohon } \\
\text { /ancak }\end{array}$ & $\begin{array}{c}\text { Hari } \\
\text { Sadap/th }\end{array}$ & $\begin{array}{c}\text { Produktivitas } \\
(\mathrm{kg} / \mathrm{ha} / \mathrm{th})\end{array}$ \\
\hline QS rekom & $\begin{array}{l}\mathrm{S} / 2 \mathrm{~d} 3 . \\
\mathrm{ET} 2.5 \% 6 / \mathrm{y}\end{array}$ & BO-2 & 45 & $100 \%$ & 450 & 100 & 2.025 \\
\hline QS d4 & $\begin{array}{l}\text { S/2 d4. } \\
\text { ET2.5\% 18/y }\end{array}$ & BO-2 & 51 & $83 \%$ & 450 & 75 & 1.721 \\
\hline Q-tap & $\begin{array}{l}\text { S/3Ud3. } \\
\text { ET2.5\% 9/y } \\
\text { S/2 d3 }\end{array}$ & $\mathrm{HO}-$ & 57 & $75 \%$ & 450 & 100 & 2.565 \\
\hline SS rekom & $\begin{array}{l}\mathrm{S} / 2 \mathrm{~d} 3 . \\
\mathrm{ET} 2.5 \% 18 / \mathrm{y}\end{array}$ & $\begin{array}{l}\mathrm{BO}-2 \\
\mathrm{BO}-2\end{array}$ & 36 & $100 \%$ & 450 & 100 & 1.620 \\
\hline SS d4 & $\begin{array}{l}\mathrm{S} / 2 \mathrm{~d} 4 . \\
\mathrm{ET} 4.0 \% 18 / \mathrm{y}\end{array}$ & BO-2 & 47 & $103 \%$ & 450 & 75 & 1.586 \\
\hline $\mathrm{SS} a b$ & $\begin{array}{l}\mathrm{S} / 2 \mathrm{~d} 3 . \\
\mathrm{ET} 2.5 \% 18 / \mathrm{y}\end{array}$ & BO-2 & 36 & $100 \%$ & $700 *$ & 100 & $1.620 * *$ \\
\hline SS d6 & $\begin{array}{l}\text { S/2 d6. } \\
\text { ET5.0\% 18/y }\end{array}$ & BO-2 & 52 & $100 \%$ & 450 & 50 & 1.170 \\
\hline
\end{tabular}

Upaya meningkatkan produktivitas dengan biaya yang normal sehingga perolehan keuntungan masih cukup memadai merupakan solusi terbaik pada pengusahaan perkebunan karet dengan potensi klon QS. Sistem sadap Q-tap merupakan konsep baru sistem sadap pada klon QS yang dianggap sesuai dengan kondisi wilayah Utara
Sumatra. Sistem sadap Q-tap diharapkan akan menghasilkan produktivitas tinggi dengan kumulatif yield 35 ton/ha/siklus dalam periode hanya 15 tahun sadap. Konsep ini belum diterapkan di lapangan namun memberi peluang/harapan lebih optimistis dan realistis pada wilayah yang bersangkutan. Peluang lain yang 
dimungkinkan adalah penerapan LD (Latex Diagnosis) secara langsung.

Pembandingan sistem sadap pada kelompok klon SS (umur TM 7) menghasilkan produksi tidak terlalu tinggi (Tabel 3). Produksi tertinggi diantara masingmasing sistem sadap hanya mencapai 1.620 $\mathrm{kg} /$ ha yaitu pada sistem sadap SS rekom/SS $\mathrm{ab}$, kemudian SS d4 sekitar $1.586 \mathrm{~kg} / \mathrm{ha}$, dan terendah pada sistem sadap SS d6 sekitar $1.170 \mathrm{~kg} / \mathrm{ha}$. Pada sistem sadap SS d4 atau SS d6 dengan menambah konsentrasi stimulan mampu menaikkan $\mathrm{g} / \mathrm{p} / \mathrm{s}$, namun produksi kumulatif selama satu tahun $<1.600$ $\mathrm{kg} / \mathrm{ha}$ akibat jumlah hari sadap sedikit (75 dan 50 hari).

Upaya memperoleh margin keuntungan yang memadai pada klon SS berpeluang dilakukan melalui efisiensi/penekanan biaya panen, misalnya dengan menurunkan $\mathrm{HK}$ dari frekuensi d3 menjadi d4 (dengan kompensasi stimulasi lebih tinggi, ET4\%). Melalui penurunan HK secara otomatis akan menurunkan komponen biaya panen. Selanjutnya frekuensi sadap dapat ditekan lebih rendah lagi menjadi d6 (dengan kompensasi stimulasi lebih tinggi lagi, ET5\%). Hasilnya akan terlihat menurunkan biaya panen menjadi lebih rendah lagi, namun nampaknya potensi keuntungannya masih rendah karena produksi yang timbul sebagai reaksi ternyata juga menurun.

Upaya lain yang dilakukan suatu perusahaan melalui perluasan ancak yaitu dengan menambahkan populasi pohon per ancak menjadi 700 pohon. Dengan menambah populasi pohon per ancak namun HK-nya tetap $\mathrm{d} 3$, mampu memberikan potensi keuntungan terbesar dalam kelompok sistem sadap SS. Yang perlu ditekankan adalah sistem sadap ancak besar (SS ab) dibandingkan dengan sistem sadap SS rekom memiliki potensi produksi per hektar yang sama. Penggunaan ancak besar ternyata tidak menambah produksi per hektarnya, namun lebih meningkatkan prestasi tenaga kerja dengan menekan penggunaan tenaga kerja dari sisi jumlah penyadap dan luas areal sadap. Jika dilakukan dalam jangka panjang,
SS ancak besar kurang sustainable, karena kapasitas/norma kerja penyadap di atas normal dan waktu penyadapan panjang dengan tekanan turgor rendah mungkin berpengaruh terhadap kesehatan tanaman dalam jangka panjang. Peluang yang dapat memberikan produksi optimal pada SS dan biaya yang efisien mungkin adalah penerapan LD secara langsung.

\section{Analisis Finansial}

Kegiatan penyadapan merupakan kegiatan yang memerlukan biaya produksi terbesar karena mencapai $33-44 \%$ FOB sehingga selalu menjadi perhatian utama apabila terjadi perubahan harga komoditas (Sumarmadji et al., 2009). Berbagai cara dilakukan untuk menekan biaya panen, salah satunya dengan sistem sadap intensitas rendah melalui kombinasi hari sadap dan stimulan. Analisis dilakukan melalui tiga pendekatan biaya, yaitu biaya penyadapan yang terdiri dari: upah penyadap, premi, aplikasi etefon, kemudian biaya produksi tingkat kebun (ex-factory cost) dan biaya produksi hingga lateks diolah di pabrik.

Dalam analisis pertama, biaya panen yang diperhitungkan adalah terbatas pada upah penyadap termasuk premi, dan penggunaan etefon. Alokasi upah penyadap merupakan yang terbesar dibandingkan dengan biaya lainnya, terutama pada sistem sadap d3 yang memerlukan 100 hari sadap per tahun, dan semakin menurun untuk sistem sadap d4 dan d6. Pembayaran premi juga memiliki peranan penting dalam menentukan biaya penyadapan, terutama premi produksi yang akan semakin meningkat seiring dengan meningkatnya produksi yang dicapai. Pemberian premi tersebut sangat penting untuk memotivasi penyadap agar menghasilkan produktivitas yang tinggi pula. Pada sistem sadap Q-tap, meskipun memiliki jumlah hari sadap dan upah penyadap sama dengan sistem sadap berbasis d3 lainnya, namun biayanya paling tinggi karena tambahan premi produksi. Namun demikian, Q-tap mampu menghasilkan penerimaan tertinggi dan potensi keuntungan tertinggi 
karena produktivitas yang dihasilkan paling tinggi, yaitu $2.565 \mathrm{~kg} / \mathrm{ha} /$ th (Gambar 5).

Dari selisih penerimaan dengan biaya penyadapan diperoleh potensi keuntungan tertinggi pada sistem sadap Q-tap (Rp 26.940.800,- per ha/th), sedangkan yang terendah adalah sistem sadap SS d6 (Rp 12.955.600,- per ha/th). Pada sistem sadap SS d6, meskipun memiliki biaya penyadapan terendah, ternyata menghasilkan potensi keuntungan yang paling rendah pula, karena produktivitasnya yang rendah.

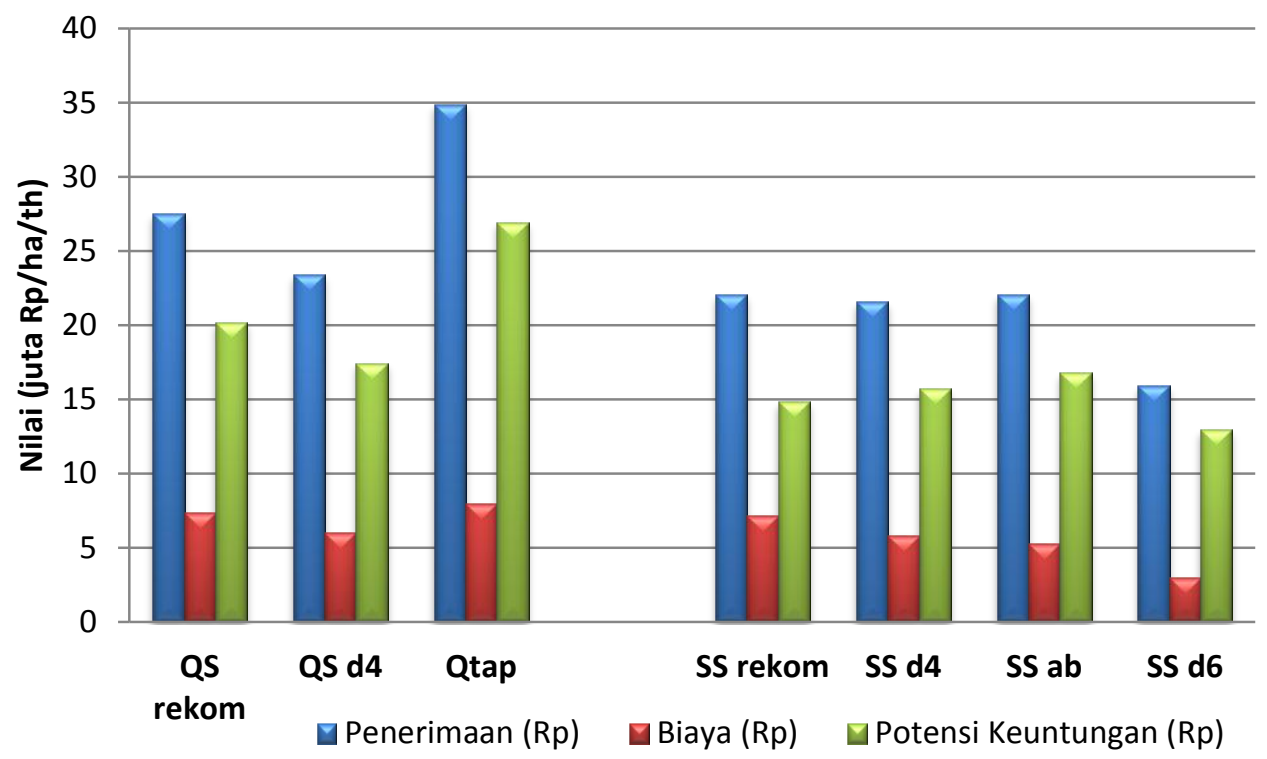

Gambar 5. Perbandingan potensi keuntungan semua alternatif sistem sadap terhadap masingmasing komponen biaya panen

Asumsi :

Harga jual karet (85\% FOB)

Kurs dollar terhadap rupiah

$=\operatorname{Rp} 13.600 / \mathrm{kg}$

$=\mathrm{Rp} 13.700,-$

Upah penyadap yang berlaku di Jawa Tengah $=\mathrm{Rp} 52.000,-/ \mathrm{HKO}$

Harga etefon

$=\mathrm{Rp} 78.000,-/ 1 \mathrm{t}$

Pada kelompok QS, perubahan sistem sadap menjadi $\mathrm{d} 4$ memang mampu menekan biaya hingga $19 \%$ dari QS rekom ( $R p 7,3$ juta) menjadi QS d4 (Rp 5,9 juta), namun potensi keuntungan yang dihasilkan oleh QS d4 lebih rendah 13\% daripada QS rekom. Sedangkan pada kelompok SS, perubahan sistem sadap dari SS rekom (d3) menjadi d4 dan d6 mampu menekan biaya hingga 19\% (Rp 5,8 juta) dan 59\% (Rp 2,9 juta). Namun demikian, potensi keuntungan SS d4 mampu menjadi yang tertinggi yaitu senilai $R p$ 15,7 juta dibanding SS rekom dan SS d6.

Pada sistem sadap SS ab, ketika dihitung dengan pendekatan luasan hektar lahan, menghasilkan produksi yang sama dengan SS rekom, dengan biaya sadapan lebih rendah, yaitu semula SS rekom (Rp 7,1 juta) menjadi SS ab (Rp 5,2 juta) atau ada penghematan biaya $27 \%$ dari SS rekom. Penghematan biaya tersebut juga mampu menghasilkan potensi keuntungan SS ab yang lebih tinggi dari SS rekom, yaitu sebesar 13\%. Dari analisis tersebut, menunjukkan bahwa perubahan sistem sadap dari $\mathrm{d} 3$ menjadi $\mathrm{d} 4$ memang mampu menekan biaya hingga $19 \%$, namun potensi keuntungannya pada QS d4 lebih rendah 13\% daripada QS rekom, sedangkan potensi keuntungan pada SS d4 lebih tinggi $6 \%$ daripada SS rekom.

Pada analisis kedua, biaya yang dianalisa merupakan biaya produksi tingkat kebun sebelum masuk ke pabrik pengolahan (exfactory cost), yang terdiri dari (1) gaji, biaya 
sosial, tunjangan, (2) biaya pemeliharaan TM, (3) biaya panen. Dalam Gambar 6, menunjukkan bahwa selisih penerimaan dan biaya semakin tipis, karena semakin besarnya biaya yang diperhitungkan, namun kondisi secara umum masih menguntungkan kecuali sistem sadap SS d6. Pola yang terbentuk juga sama, yaitu sistem sadap Q-tap memiliki penerimaan, biaya dan keuntungan yang tertinggi yaitu $\mathrm{Rp} 12,8$ juta,-/ha/th, sedangkan yang merugi adalah sistem sadap d6, yaitu Rp 1,1 juta,-/ha/th. Kenyataannya, pada sistem sadap d6 penerimaan yang dhasilkan dari perkalian produksi $(1.170 / \mathrm{kg} / \mathrm{ha} / \mathrm{th})$ dengan harga jual $\mathrm{Rp}$ $13.600,-(85 \%$ FOB $)$ tidak mampu menutupi biaya yang diperlukan, sehingga terjadi kerugian.

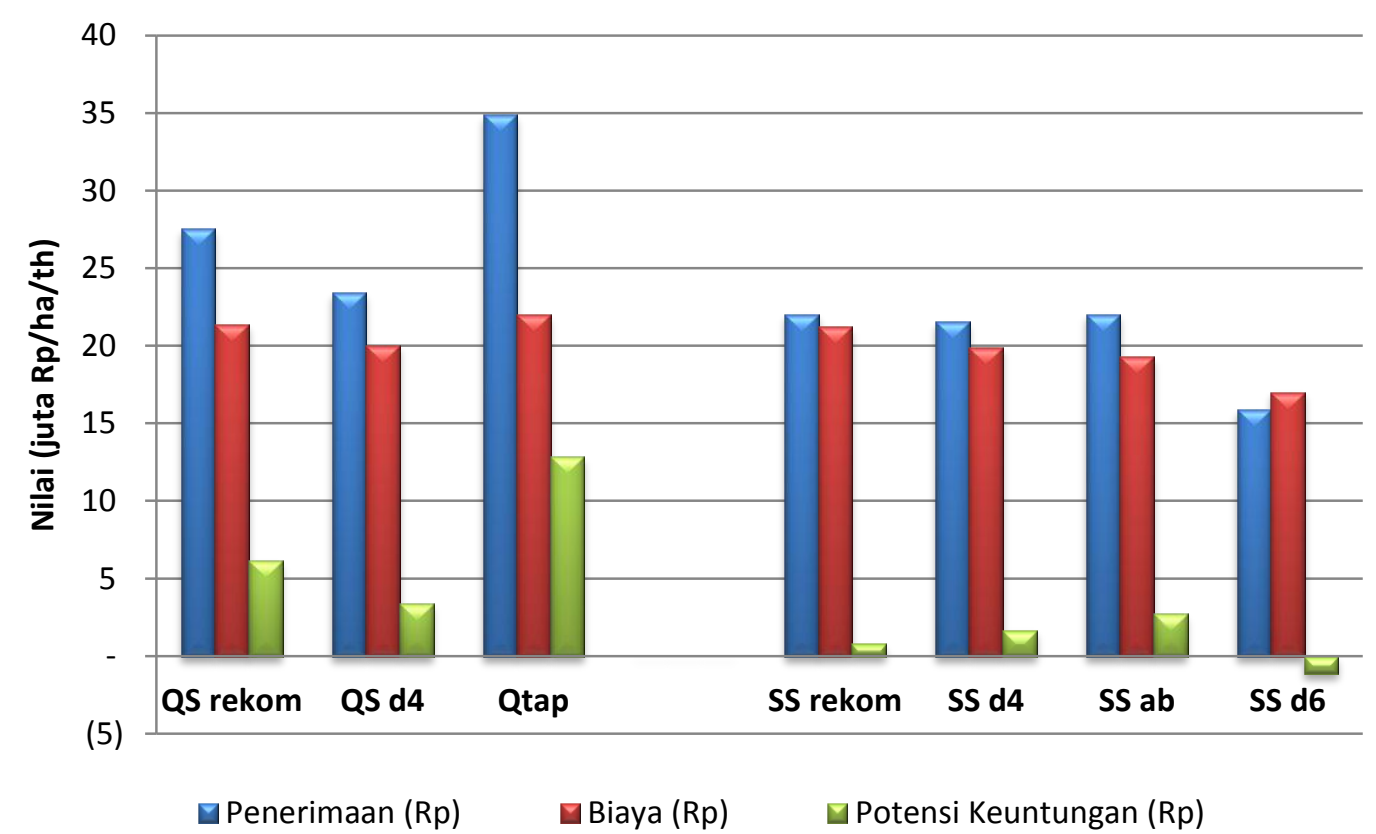

Gambar 6. Perbandingan potensi keuntungan semua alternatif sistem sadap pada masing-masing biaya produksi (ex-factory cost)

Asumsi :

Harga jual karet (85\% FOB)

Kurs dollar terhadap rupiah

Upah penyadap yang berlaku di Jawa Tengah

Harga etefon

Pada analisis ketiga, biaya yang diperhitungkan adalah biaya sampai lateks sudah diolah di pabrik, yaitu biaya yang digunakan dalam analisa kedua ditambah biaya transportasi dan pengolahan di pabrik, dapat dijabarkan pada Tabel 4. Dalam hal ini, harga yang diperhitungkan adalah 100\%

$$
\begin{aligned}
& =\operatorname{Rp~13.600/kg~} \\
& =\operatorname{Rp} 13.700,- \\
& =\operatorname{Rp} 52.000,-/ \mathrm{HKO} \\
& =\operatorname{Rp} 78.000,-/ 1 \mathrm{t}
\end{aligned}
$$

FOB ( $\mathrm{Rp} 16.000,-/ \mathrm{kg})$. Secara umum, dengan asumsi tersebut diperoleh hasil bahwa semua sistem sadap klon SS (SS rekom, SS d4, SS ab dan SS d6) mengalami kerugian, sedangkan sistem sadap QS (QS rekom, QS d4 dan Q-tap) mengalami keuntungan. 
Tabel 4. Perbandingan keuntungan semua alternatif sistem sadap pada masing-masing biaya

\begin{tabular}{lcll}
\hline \multicolumn{1}{c}{ Sistem sadap } & Penerimaan $(\mathrm{Rp})$ & Biaya $(\mathrm{Rp})$ & Keuntungan $(\mathrm{Rp})$ \\
\hline QS rekom & 32.400 .000 & 29.581 .215 & 2.818 .785 \\
QS d4 & 27.540 .000 & 27.134 .323 & 405.677 \\
Q-tap & 41.040 .000 & 32.101 .935 & 8.938 .065 \\
SS rekom & 25.920 .000 & 27.972 .825 & $(2.052 .825)$ \\
SS d4 & 25.380 .000 & 26.518 .993 & $(1.138 .993)$ \\
SS ab & 25.920 .000 & 26.038 .825 & $(118.825)$ \\
SS d6 & 18.720 .000 & 22.151 .725 & $(3.431 .725)$ \\
\hline
\end{tabular}

Asumsi :

Harga jual karet $(100 \%$ FOB $) \quad=$ Rp $16.000 / \mathrm{kg}$

Kurs dollar terhadap rupiah $\quad=\mathrm{Rp} 13.700,-$

Upah penyadap yang berlaku di Jawa Tengah $\quad=\mathrm{Rp} 52.000,-/ \mathrm{HKO}$

Harga etefon $\quad=\mathrm{Rp} 78.000,-/ 1 \mathrm{t}$

\section{Kesimpulan dan Saran}

Pendekatan masalah dapat ditempuh melalui dua orientasi, 1) produksi tinggi dengan biaya normal, dan 2) produksi normal dengan biaya rendah. Kedepan mungkin dapat ditempuh melalui implementasi LD (Latex Diagnosis) secara langsung.

Secara finansial pada tingkat biaya langsung penyadapan menunjukkan bahwa potensi keuntungan tertinggi hingga terendah secara berurutan adalah Q-tap, QS rekom, QS d4, SS ab, SS d4, SS rekom dan SS d6, berkisar antara $\mathrm{Rp} 26,9$ juta hingga $\mathrm{Rp} 12,9$ juta per ha. Pada tingkat kebun, potensi keuntungan terjadi pada semua sistem sadap, kecuali sistem sadap d6. Pada tingkat bahan baku (sudah memasukkan biaya olah di pabrik), potensi keuntungan terjadi pada semua sistem sadap klon QS sebesar Rp 405 ribu hingga $\mathrm{Rp} \mathrm{8,9} \mathrm{juta} \mathrm{per} \mathrm{ha,} \mathrm{namun} \mathrm{semua}$ sistem sadap klon SS mengalami kerugian. Sistem d6 merupakan sistem yang paling rendah biaya dan tingkat potensi keuntungannya (kerugian tertinggi) karena penerimaan yang jauh lebih rendah daripada biayanya, akibat dari produktivitasnya yang sangat rendah. Sedangkan sistem Q-tap, menggambarkan kondisi sebaliknya dari sistem d6, meskipun sistem Q-tap mampu memberikan potensi keuntungan tertinggi, ternyata menggunakan biaya tertinggi pula. Semua sistem SS (SS rekom, SS d4, SS ab, dan SS d6) mengalami kerugian. Kegiatan penekanan biaya belum tentu mampu meningkatkan keuntungan, seperti terjadi pada QS d4, SS rekom, SS d4, SS ab, dan SS d6.

Dalam pengusahaan perkebunan karet (terutama kondisi harga rendah), wilayah Utara katulistiwa dengan potensi klon QS disarankan untuk menggunakan sistem sadap Q-tap yang merupakan sistem sadap berorientasi produksi tinggi, sebaliknya pada wilayah Selatan katulistiwa dengan potensi klon SS disarankan untuk menggunakan sistem sadap SS d4. Sistem sadap SS ab meskipun memberi nilai yang lebih tinggi, kurang disarankan karena kurang sustainable. Agar hasil pengusahaan tanaman karet dapat memperoleh margin keuntungan terbaik, tanaman sehat dan produktif berkelanjutan, kiranya dalam jangka panjang dapat disarankan untuk menerapkan LD (Diagnosis Lateks) secara langsung. 


\section{Daftar Pustaka}

Azwar, R. dan Suhendry, I. (1998). Kemajuan pemuliaan karet dan dampaknya terhadap peningkatan produktivitas. Prosiding Lokakarya Pemuliaan 1998\& Diskusi Nasional Prospek Karet Alam Abad 21, Medan, Desember 1998.

Basuki. (1983). Eksploitasi Karet. Seminar dan Lokakarya tentang Eksploitasi Karet. Tanjung Morawa, Oktober 1983.

Bukit, E., Aidi-Daslin., dan Karyudi. (2006). Kajian ekonomi penggunaan klon karet anjuran quick dan slow starter. Prosiding Lokakarya Nasional Budidaya Tanaman Karet, Medan, September 2006.

Gohet, E., Prevot, J. E., Eschbach, J. M., Clement, A., and Jacob, J. L. (1996). Clone croisance et stimulation, facteurs de la production de latex. Plantations, recherche, developpement, 3(1), 30-38.

Jacob, J. L., Prevot, J.C., Lacrotte, R., Clement, A., Serres, E., and Gohet, E. (1995). Typologie Clonale du Fonctionnement des Laticiferes chez Hevea brasiliensis. Plantations, recherche, developpement, 2(5), 43-49.

Jacob, J. L., Prevot, J. C., and Kekwick, R. G. O. (1989). General metabolism Hevea brasiliensis latex. In J. d'Auzac and $\mathrm{H}$. Chrestin (Eds). Physiology of rubber tree latex. Boca Raton : CRC Press.

Junaidi, U., Kuswanhadi., dan Tjasadihardja, A.(1995). Respons klon karet anjuran terhadap berbagai sistem sadap. Prosiding Lokakarya Nasional Pemuliaan Tanaman Karet, Medan,November 1995.

Junaidi, U. dan Kuswanhadi. (1997). Sistem sadap ke arah atas sebagai alternatif dari sistem sadap ke arah bawah pada klon anjuran. Jurnal Penelitian Karet, 15(1), 112.

Kurnia, D. (2006). Sistem penyadapan dengan intensitas rendah dalam skala komersial di PT Socfin Indonesia. Prosiding Lokakarya Nasional Budidaya Tanaman Karet, Medan, September 2006.
Lukman. (1995). Penggunaan sadapan ke arah atas (SKA) dengan intensitas eksploitasi rendah untuk meningkatkan produksi dan umur ekonomi tanaman karet. Jurnal Penelitian Karet, 13(2), 85-98.

Nang, N., Hai, T. V., Thanh, D. K., Luyen, P. V., Tuan, T. V., Thai, N. V., Viet, N. Q., and Thui, K. T. (2015). The yield and latex physiological parameters on $\mathrm{d} 3$ and d4 tapping system of PB 260 clone at Shoutheast Region in Vietnam. Proceeding International Rubber Conference 2015, Ho Chi Minh City,November 2015.

Obouayeba, S., Diarrassouba, M., Soumahin, E. F., and Essehi, J. L.(2015). Latex harvesting technology adapted to clones IRCA 18, IRCA 111, IRCA 130, PB 235 and PB 260 of Hevea brasiliensis of the class to active metabolism in SouthWestern Cote d'Ivoire. Proceeding International Rubber Conference 2015, Ho Chi Minh City, November 2015.

Rachmawan, A., Tistama, R., dan Sumarmadji. (2006). Urgensi diagnosis lateks dalam mendukung produktivitas peremajaan karet yang optimal. Warta Perkaretan, 13(1), 25-35.

Siregar, T.H.S., Junaidi., Sumarmadji., Siagian, N., dan Karyudi. (2008). Perkembangan penerapan rekomendasi sistem eksploitasi tanaman karet di Perusahaan Besar Negara. Prosiding Lokakarya Nasional Agribisnis Karet, Yogyakarta, Agustus 2008.

Siregar, T. H. S., Bukit, E., danFauzi, I. R. (2013). Kelangkaan penyadap dan upaya mengatasi.Workshop Eksploitasi Tanaman Karet Menuju Produktivitas Tinggi dan Umur Ekonomis Optimal, Medan, Maret 2013.

Sumarmadji. (1999). Respons karakter fisiologi dan produksi lateks beberapa klon tanaman karet terhadap stimulasi etilen. Doktor. Disertasi, Institut Pertanian Bogor.

Sumarmadji. (2000). Sistem eksploitasi tanaman karet yang spesifik-diskriminatif. Warta Pusat Penelitian Karet, 19(1-3), 31 39. 
Sumarmadji. (2004). Sistem eksploitasi optimal pada beberapa klon karet. Jurnal Penelitian Karet, 22(2), 70- 80.

Sumarmadji. (2005). Pengaruh penyadapan intensitas rendah terhadap produksi dan serangan KAS. Jurnal Penelitian Karet, 23(1), $58-67$.

Sumarmadji dan Tistama, R. (2004). Diskripsi klon karet berdasarkan karakter fisiologi lateks untuk menetapkan sistem eksploitasi yang sesuai. Jurnal Penelitian Karet, 22(1), 27-40.

Sumarmadji., Karyudi., dan Siregar, T. H. S. (2006). Rekomendasi sistem eksploitasi pada klon quick dan slow starter serta penggunaan irisan ganda untuk meningkatkan produktivitas tanaman karet. Prosiding Lokakarya Nasional Budidaya Tanaman Karet, Medan, September 2006.

Sumarmadji dan Junaidi. (2008). Perakitan sistem sadap EXPEX-315 pada klon quickstarter. Jurnal Penelitian Karet, 26(2), 153-165.
Sumarmadji., Junaidi., dan Atminingsih. (2009). Perkembangan sistem eksploitasi dalam upaya pencapaian produktivitas optimal. Warta Pusat Penelitian Karet, 28(2), $61-72$.

Syarifa, L.F, Thomas., dan Sumarmadji. (2006). Kajian Ekonomis Sistem Sadap dengan Perbedaan Frekuensi Sadap dan Aplikasi Stimulan di Perkebunan Besar dalam Kaitannya dengan Perubahan Harga Karet. Prosiding Lokakarya Nasional Budidaya Tanaman Karet, Medan, September 2006.

Ting. G. L., Cheng, C. O., Yee, H. C., Wood, B. J. (1985). Stimulation regines to reducedtapping intensity on panels BO-1 and BO-2 of RRIM 600, GT 1 and PB16/661 seedling. International Rubber Conference, Kuala Lumpur, Oktober 1985.

Tistama, R. dan Siregar, T. H. S. (2005). Perkembangan Penelitian Stimulan untuk Pengaliran Lateks Hevea Brasiliensis. Warta Perkaretan , 24(2), 45-57. 
Lampiran 1. Standar Produktivitas Tanaman Karet Klon Quick Starterdalam Satu Siklus Ekonomi

\begin{tabular}{|c|c|c|c|c|}
\hline $\begin{array}{c}\text { Tahun } \\
\text { Sadap }\end{array}$ & gps & ph/ha & hari/th & $\mathrm{kg} / \mathrm{ha} / \mathrm{th}$ \\
\hline 1 & 22 & 500 & 80 & 880 \\
\hline 2 & 35 & 530 & 110 & 2041 \\
\hline 3 & 40 & 540 & 110 & 2376 \\
\hline 4 & 44 & 520 & 110 & 2517 \\
\hline 5 & 42 & 510 & 110 & 2356 \\
\hline 6 & 50 & 490 & 110 & 2695 \\
\hline 7 & 52 & 440 & 110 & 2517 \\
\hline 8 & 65 & 400 & 110 & 2860 \\
\hline 9 & 63 & 380 & 110 & 2633 \\
\hline 10 & 65 & 360 & 110 & 2574 \\
\hline 11 & 63 & 340 & 110 & 2356 \\
\hline 12 & 62 & 320 & 110 & 2182 \\
\hline 13 & 60 & 300 & 110 & 1980 \\
\hline 14 & 62 & 290 & 110 & 1978 \\
\hline 15 & 60 & 280 & 110 & 1848 \\
\hline 16 & 55 & 260 & 110 & 1573 \\
\hline 17 & 52 & 240 & 110 & 1373 \\
\hline 18 & 50 & 220 & 115 & 1265 \\
\hline 19 & 50 & 210 & 115 & 1208 \\
\hline 20 & 40 & 200 & 115 & 920 \\
\hline & & & TOTAL & 40131 \\
\hline
\end{tabular}

Lampiran 2. Standar Produktivitas Tanaman Karet Klon Slow Starterdalam Satu Siklus Ekonomi

\begin{tabular}{|c|c|c|c|c|}
\hline $\begin{array}{l}\text { Tahun } \\
\text { Sadap }\end{array}$ & gps & $\mathrm{ph} / \mathrm{ha}$ & hari/th & $\mathrm{kg} / \mathrm{ha} / \mathrm{th}$ \\
\hline 1 & 15 & 500 & 80 & 600 \\
\hline 2 & 23 & 530 & 110 & 1341 \\
\hline 3 & 26 & 540 & 110 & 1544 \\
\hline 4 & 30 & 520 & 110 & 1716 \\
\hline 5 & 27 & 510 & 110 & 1515 \\
\hline 6 & 32 & 500 & 110 & 1760 \\
\hline 7 & 36 & 450 & 110 & 1782 \\
\hline 8 & 35 & 420 & 110 & 1617 \\
\hline 9 & 34 & 410 & 110 & 1533 \\
\hline 10 & 32 & 400 & 110 & 1408 \\
\hline 11 & 55 & 390 & 110 & 2360 \\
\hline 12 & 52 & 380 & 110 & 2174 \\
\hline 13 & 55 & 370 & 110 & 2239 \\
\hline 14 & 50 & 360 & 110 & 1980 \\
\hline 15 & 52 & 350 & 110 & 2002 \\
\hline 16 & 50 & 340 & 110 & 1870 \\
\hline 17 & 52 & 330 & 110 & 1888 \\
\hline 18 & 50 & 320 & 110 & 1760 \\
\hline 19 & 45 & 310 & 115 & 1604 \\
\hline 20 & 40 & 300 & 115 & 1380 \\
\hline & & & TOTAL & 34072 \\
\hline
\end{tabular}

